\title{
Expression of heat shock protein and trehalose-6-phosphate synthase homologues induced during water deficit in cotton
}

\author{
Alexandre Lima Nepomuceno, ${ }^{1, *}$, Derrick Oosterhuis ${ }^{2}$, James McD Stewart ${ }^{2}$, Rickie Turley ${ }^{3}$, Norman Neumaier ${ }^{1}$ \\ and José Renato Bouças Farias ${ }^{1}$ \\ ${ }^{1}$ EMBRAPA - Centro Nacional de Pesquisa de Soja, CP 231, 86001-970, Londrina, PR, Brasil; ' ${ }^{2}$ University of Arkansas, Department \\ Crop, Soil, and Environmental Sciences, PTSC 115, Fayetteville, AR, 72701, USA; ${ }^{3}$ USDA ,Agricultural Research Service, P.O. Box \\ 345, Stoneville, MS, 38776, USA; *Corresponding author: anepo@cnpso.embrapa.br
}

Tolerance to drought in plants is not a simple trait, but a complex of mechanisms working in combination to avoid or to resist water deficit. Genotypes that differ in tolerance to water deficit may show qualitative and quantitative differences in gene expression when submitted to drought periods. Four cotton (Gossypium hirsutum L.) genotypes (Siokra L-23, Stoneville 506, CS 50 and T1521) with contrasting responses to water deficit stress were studied using the Differential Display (DD) technique to identify and isolate genes which may differ among them. Fifty-two cDNA fragments differentially expressed during water deficit were isolated, cloned and sequenced. Search of gene bank databases showed that two cDNA clones, A12B15-6 and A12B13-1, have high homology with a heat shock protein that binds to calmodulin found in Nicotiana tabacum (2.9e-32 P(N)) and with an Arabidopsis thaliana trehalose-6-phosphate synthase enzyme $(9.0 \mathrm{e}-37 \mathrm{P}(\mathrm{N}))$, respectively. One of the presumed functions of heat shock proteins is related to prevention of protein denaturation during cellular dehydration. Trehalose-6-phosphate synthase is involved in the production of trehalose, a disaccharide known to osmotically protect cell membranes during dehydration. The HSP homologue was found to be differentially expressed during the drought period in two drought tolerant genotypes but not in drought-sensitive genotypes. The trehalose-6-phosphate synthase homologue was also up-regulated during water deficit stress, however, all four genotypes were induced to express this homologue. Ribonuclease protection assays confirmed these results. This is an important finding since there are only few reports of trehalose presence in higher plants and none in cotton.

Key words: calmodulin, drought, gene expression, Gossypium hirsutum L., trehalase.

Expressão de homólogos de uma proteína de choque térmico e da enzima trehalose-6-fosfato sintase durante déficit hídrico em algodão: Tolerância à seca em plantas não é uma característica simples, mas sim um complexo de mecanismos trabalhando em combinação para evitar ou tolerar períodos de déficit hídrico. Genótipos que diferem em tolerância à déficits hídricos apresentam diferenças qualitativas e quantitativas de expressão gênica. Quatro genótipos de algodão (Gossypium hirsutum L.) (Siokra L23, Stoneville 506, CS 50 e T-1521) que apresentam distintas respostas quando submetidos ao déficit hídrico, foram estudados pelo uso da técnica "Differential Display - (DD)". Com esta técnica é possivel identificar e isolar genes diferencialmente expressos nestes genótipos. Cinquenta e dois fragmentos de DNA complementar (DNAc) foram isolados, clonados e seqüenciados. Análises em bancos de dados mostraram que dois clones de DNAc, A12B15-6 e A12B13-1 tem alta homologia com uma proteína de choque térmico que adere a calmodulin, e é encontrada em Nicotiana tabacum (2.9e-32 P(N)) e com a enzima trehalose-6fosfato sintase de Arabidopsis thaliana $(9.0 \mathrm{e}-37 \mathrm{P}(\mathrm{N}))$, respectivamente. Uma das funções propostas para as proteínas de choque térmico (HSP) é a de prevenir a desnaturação de proteínas durante a desidratação celular. A enzima trehalose-6-fosfato sintase esta envolvida na produção de trehalose, um disacarídio conhecido por estar envolvido na proteção de membranas celulares durante a desidratação. O homólogo da HSP foi encontrado diferencialmente expresso durante o período de seca em dois genótipos tolerantes à seca, mas não nos genótipos sensíveis. O homólogo da enzima trehalose-6-fosfato sintase foi também induzido durante o déficit hídrico, entretanto, todos os quatro genótipos expressaram este homólogo. Ensaios protegidos de ribonucleases confirmaram os resultados.

Palavras-chave: calmodulina, seca, expressão gênica, Gossypium hirsutum L., trehalase. 


\section{INTRODUCTION}

Since plants started to emerge 1.5 billion years ago (Lehninger et al., 1993) evolutionary pressure has shaped plant responses to water deficit resulting in a complex web of responses. These responses start with stress perception, which initiates signal transduction pathways, and end in changes at many metabolic, physiological and developmental levels. Therefore, responses to drought will be conditioned not only by the nature and intensity of the environmental factors involved, but also by the ecological histories of species, ecotypes, cultivars and genotypes. As a consequence, a large range of molecular, biochemical and physiological responses arise when plants are submitted to periods of water deficit. Several genes are likely to be involved in each drought tolerance trait. Accordingly, molecular biology and plant physiology together can aid identifying and selecting these genes, and determine their influence in yield (Turner, 1997). Differently expressed genes are usually identified by comparing mRNA abundance (Wan et al., 1996). Therefore, a partial understanding of these developmental events may be obtained by analyzing and comparing mRNAs isolated from well-watered and waterstressed plants.

The change in cell volume that accompanies the early stages of water deficit in plants may trigger stretch-activated channels, alter the conformation or the juxtaposition of critical sensory proteins, or cause alterations in the cell wall-plasmalemma continuum, thereby activating signal transduction pathways that elicit gene expression (Hare et al., 1996; Shinozaki \& Yamaguchi-Shinozaki, 1996, 1997). Many water-deficit-induced genes encode proteins predicted to protect cellular structures and functions from the effects of water loss and to promote some cellular osmotic potential adjustments to increase water uptake, while others will control ion accumulation and further gene expression regulation (Bray, 1993, 1997; Boyer, 1996; Shen et al., 1997).

Heat-shock proteins (HSP) are a group of gene products usually found in plants subjected to water deficit (Vierling, 1991; Joshi and Nguyen, 1996). As the name suggests, HSP were first identified as responses to heat stress. The ability to respond to mild temperature shock by the synthesis of HSP within few hours of the shock is a general response and has been observed in microbes and animals as well as in plants (Harborne, 1997). Most of the HSP probably function as molecular chaperones that assist in protein folding and prevent protein denaturation (Zhu et al., 1993). Some HSP are normally produced by the cell, while during stress more HSP are necessary because protein aggregation and denaturation are increased (Cooper, 1997). Increased synthesis of HSP may help protect these proteins during the osmotic stress that follows cell dehydration (Zhu et al., 1997).

HSP are highly conserved in both prokaryotic and eukaryotic cells (Cooper, 1997). Several classes of HSP have been described in eukaryotes, including plants. They are designated by their approximate molecular weights in kDa as HSP110, HSP90, HSP70, HSP60, and low molecular weight (LMW) HSP (15-30 kDa) (Vierling, 1991). The HSP70 and HSP60 families appear to be particularly important in the general pathways of protein folding in both prokaryote and eukaryote cell. Both HSP families function by binding to unfolded regions of polypeptides chains (Cooper, 1997).

Soluble sugars have also been reported to act as protectants during cell dehydration (Leprince et al., 1993; Boyer, 1996). Trehalose is one of the most effective osmoregulatory sugars in terms of the minimal concentration required. It has been reported in many organisms, however, there are only a few reports in higher plants (Ingram and Bartels, 1996). Trehalose seems to play many roles in increasing tolerance to dehydration (Potts, 1994; Boyer, 1996). One role is to bind to the cell membrane and lower its melting temperature, thereby keeping the membrane in its liquid crystalline phase (Crowe et al., 1993). In addition, trehalose stabilizes enzymes (Carpenter et al., 1987) and vesicles (Crowe et al., 1993) during cell dehydration. Sucrose and maltose have also been shown to have protective effects over enzymes and membranes (Carpenter et al., 1987; Boyer, 1996). During mild water deficit, water potential can be maintained by osmotic adjustment, and sugars may serve as compatible solutes lowering the osmotic potential. Resurrection plants, such as Craterostigma plantagineum, and drought sensitive plants, like spinach (Spinacea oleracea) both increase sucrose synthesis and sucrose-phosphate synthase activity during water deficit (Ingram and Bartels, 1996).

Water deficit is a major concern in cotton production. The unique expression of genes in stress tolerant cotton genotypes could be used to study drought tolerance mechanisms and to identify other genotypes with similar characteristics. Identifying and understanding mechanisms 
of water stress tolerance is crucial for developing new tolerant cultivars not only in cotton, but also in other species. Therefore, the objective of this study was to identify and isolate genes that differ among four selected cotton genotypes contrasting in tolerance to water deficit.

\section{MATERIALS AND METHODS}

Four cotton (Gossypium hirsutum L.) genotypes, two water-deficit sensitive (Stoneville 506 and CS 50) and two water-deficit tolerant (Siokra L-23 and T-1521) (Oosterhuis et al., 1987; Nepomuceno et al., 1996; Nepomuceno et al., 1998) were planted in pots containing washed sand and grown under greenhouse conditions. Temperatures in the greenhouse were $30{ }^{\circ} \mathrm{C} \pm 2{ }^{\circ} \mathrm{C}$ during the day and $25{ }^{\circ} \mathrm{C} \pm$ $2{ }^{\circ} \mathrm{C}$ at night, with relative humidity near $50 \%$. Metal halide illumination lamps $(1,000 \mathrm{~W})$ were used to supplement natural radiation. Light radiation reached a maximum of $1,500 \mu \mathrm{mol} \cdot \mathrm{m}^{-2} \cdot \mathrm{s}^{-1}$ at the top of canopy at midday.

The volume of pure water added to the pots was calculated periodically to maintain the pots of the stressed treatments at $5 \%$ gravimetric humidity $(\mathrm{GH})$ and nonstressed treatments at $15 \% \mathrm{GH}$. Gravimetric humidity percentage gives the amount (weight) of water present in relation to the sand. Percentages are based on the sand dry weight. These percentages were chosen based on preliminary experiments where $5 \% \mathrm{GH}$ was found to promote mild water deficit and $15 \% \mathrm{GH}$ kept treatments near field capacity. Twice-a-week watering using balanced nutrient solution at $\mathrm{pH} 6.6$ was conducted according to Henvitt, 1963. All treatments were kept at $15 \%$ GH until 20 days after germination, after which irrigation was withheld from the stressed treatments until sand humidity reached $5 \% \mathrm{GH}$, which required approximately $48 \mathrm{~h}$. Pots were weighted twice a day (early in the morning and late in the afternoon) and water was added to keep treatments at the desired values of GH. Weekly, plants from reserve pots receiving the same treatments of the experimental pots were harvested and their weight discounted to keep the treatment pots at desired values.

Sampling times for RNA extraction were decided based on the results of previous work (Nepomuceno et al., 1998) showing that tolerant/sensitive cotton genotypes of the types used in this work reached higher differences in water and osmotic potential after 6 days of water deficit. Thus, at the $6^{\text {th }}$ day (after stress treatments reached $5 \%$
GH) leaves of the four cotton genotypes were collected for RNA isolation. The fourth leaf from the apex was sampled to obtain a $4 \mathrm{~g}$ leaf sample. Immediately after sampling, leaf tissues were rapidly and carefully washed in distilled water, blotted, and stored at $-80{ }^{\circ} \mathrm{C}$. A combination of the Wan and Wilkins (1994) and Holt (1995) hot borate extraction protocol was used for RNA isolation and quantification. A modification of the procedure by Song et al. (1995) was used for subsequent purification.

The reverse transcription reaction was performed using $2 \mu \mathrm{g}$ of purified total RNA mixed in a $200 \mu \mathrm{L}$ tube with $10 \mu \mathrm{L}$ of $5 \mathrm{x}$ M-MLV RT buffer, $1.24 \mu \mathrm{L}$ of 10 mmole. $\mathrm{L}^{-1}$ dNTP, $2.42 \mu \mathrm{L}$ anchor primer $\left(50 \mu\right.$ mole. $\left.\mathrm{L}^{-1}\right), 1$ $\mu \mathrm{L}$ RNasin (Promega, Madison, WI), and DEPC treated water to a total volume of $50 \mu \mathrm{L}$. The reaction mix was heated at $65^{\circ} \mathrm{C}$ for 5 min after which $1.5 \mu \mathrm{L}$ of Moloney Murine Leukemia Virus (M-MLV) Reverse Transcriptase (Promega, Madison, WI, 200 u. $\mu \mathrm{L}^{-1}$ ) was added to the reaction. After $1 \mathrm{~h}$ at $37^{\circ} \mathrm{C}$ the reaction mix was heated to $99^{\circ} \mathrm{C}$ for $5 \mathrm{~min}$ to inactivate the reverse transcriptase. Temperature changes were performed in a thermal cycler (Hybaid OMN-E, model P-5000-HL).

Five microliters of the reverse transcription reaction (that produced the cDNA:mRNA hybrids) were mixed in a $200 \mu \mathrm{L}$ tube with $5 \mu \mathrm{L}$ dNTP $\left(100 \mu \mathrm{mol}^{-L^{-1}}\right.$, Life Technologies, Grand Island, NY), $2.5 \mu \mathrm{L}$ 10x Taq buffer, 2.5 $\mu \mathrm{L} \mathrm{MgCl}_{2}\left(25\right.$ mmole. $\left.\mathrm{L}^{-1}\right), 0.5 \mu \mathrm{L}$ 10-mer primer $(50$ $\mu$ mole. $\left.\mathrm{L}^{-1}\right), 1 \mu \mathrm{L}$ anchor primer $\left(50 \mu\right.$ mole. $\left.\mathrm{L}^{-1}\right), 0.5 \mu \mathrm{L}^{35} \mathrm{~S}$ dATP $(1,250 \mathrm{Ci} / \mathrm{mmol}$, Amersham, Arlington Heights, IL), $0.5 \mu \mathrm{L}$ Taq polymerase $(5 \mathrm{u} / \mu \mathrm{L}$, Promega, Madison, $\mathrm{WI})$ and DEPC treated water to make a final volume of $25 \mu \mathrm{L}$. PCR cycling conditions were: $94{ }^{\circ} \mathrm{C}$ for 2 min initially, and then repeated cycles of $94{ }^{\circ} \mathrm{C}$ for $30 \mathrm{sec}, 42^{\circ} \mathrm{C}$ for 1 $\min , 72{ }^{\circ} \mathrm{C}$ for $30 \mathrm{sec}$, for 40 cycles, followed by $5 \mathrm{~min}$ final extension at $72{ }^{\circ} \mathrm{C}$ (Koonce and Haigler, Biotex Inc., Lubbock, TX, US, personal communication; Song et al., 1995). Primers were obtained (Gibco BRL, Life Technologies, Grand Island, NY) at the standard concentration of 50 nmols. Seven anchor primers $\left(\mathrm{A} 1-{ }^{5}(\mathrm{~T}){ }_{9} \mathrm{AA}^{3^{\prime}} ; \mathrm{A} 2\right.$ $5^{\prime}(\mathrm{T})_{9} \mathrm{AC}^{3^{\prime}} ; \mathrm{A} 3-{ }^{5^{\prime}}(\mathrm{T})_{9} \mathrm{CA}^{3^{\prime}} ; \mathrm{A} 5-{ }^{5^{\prime}}(\mathrm{T})_{9} \mathrm{GC}^{3^{\prime}} ; \mathrm{A} 8-{ }^{5^{\prime}}(\mathrm{T})_{9} \mathrm{CG}^{3^{\prime}}$; A11 - $\left.{ }^{\prime}(\mathrm{T})_{9} \mathrm{GG}^{3} ; \mathrm{A} 12-5^{5^{\prime}}(\mathrm{T})_{9} \mathrm{CC}^{3}\right)$ and eight ten-mers (B1 ${ }^{5} \mathrm{GAGCTTGAAC}^{3}$; B3 - ${ }^{\prime} \mathrm{CTGATCCATG}^{3}$; B5 5'TAGAGCGATC ${ }^{3} ;$ B7 - ${ }^{5} \mathrm{ATCTCGCTAG}^{3}$; B9 5'GAATTTCCCC ${ }^{3 \prime}$; B11 - 5'AGGGATCTCC ${ }^{3 \prime}$; B13 ${ }^{5} \mathrm{AAGCTGCGAG}^{3}$; B15 - ${ }^{5} \mathrm{GTGCGTCCTC}^{3}$ ) were used to screen the mRNA populations. 
A $6 \%$ denaturing polyacrylamide DNA sequencing gel was used to separate $10 \mu \mathrm{L}$ (plus $2 \mu \mathrm{L}$ gel loading dye) of the PCR products. Before loading, samples were heated at $75{ }^{\circ} \mathrm{C}$ for $3 \mathrm{~min}$. Electrophoresis was conducted at $70 \mathrm{~W}$ for $4 \mathrm{~h}$. The gel was then vacuum dried on filter paper at $80^{\circ} \mathrm{C}$ for $1.5 \mathrm{~h}$. After 2 to 3 days of autoradiography, bands were analyzed and results between water-deficit stressed and non-stressed treatments in the four cotton genotypes compared. Differentially displayed (DD) bands were then identified and extracted from the gels. The extraction and purification of DNA from the gel slices were conducted according to Ausubel et al. (1995). After extraction and purification, the band was reamplified using $10 \mu \mathrm{L}$ of the supernatant extract in a $\mathrm{PCR}$ reaction with the same primers and PCR conditions (except for ${ }^{35} \mathrm{~S}$-dATP) used during the DD. The reamplification reaction was then checked in a $2 \%$ NuSieve GTG (1x TBE buffer) agarose mini-gel.

PCR reamplifications yielding only one band were purified (Wizard PCR purification system, Promega, Madison, WI) and inserted into pGEM-T vectors according to manufacturer's instructions (Promega, Madison, WI). The concentrations of PCR product and vector were measured in a Hoefer fluorometer (TKO 100) and mixed in a molar ratio of 6:1 (insert:vector). After ligation, the pGEM-T vectors with the inserts were used to transform Escherichia coli (JM 109 strain). E. coli competent cells were prepared according to Sambrook et al. (1989). After transformation and plating, E. coli cells were incubated overnight at $37{ }^{\circ} \mathrm{C}$. Eight white colonies were then selected, spread on LB plates (with IPTG/X-Gal/ampicillin) and incubated overnight $\left(37^{\circ} \mathrm{C}\right)$ to confirm the absence of $\beta$-galactosidase activity. White colonies have the lac $\mathrm{Z}$ gene inactivated due to insertion of the reamplified cDNA fragment. Restriction of plasmid DNA extracted from the putative recombinants confirmed the cloning of fragments inserted between the appropriate recognition sites for restriction enzymes in the pGEM-T vector. Plasmid DNA was then extracted using Wizard Plus midipreps (Promega, Madison, WI). After restriction, a DNA fragment with approximately the same size as the fragment that was used in the ligation reaction was present when visualized in a $2 \%$ agarose gel.

After confirming that the correct fragments were inserted, cycle sequencing of the inserted fragments was conducted in an ALF ${ }^{\text {TM }}$ DNA automatic sequencer (Pharmacia Biotech). The reactions were performed using the ALFexpress AutoCycle sequencing kit (Pharmacia
Biotech). Database search for homology was carried out using the BLASTN2 and BLASTX2 (Altschul et al., 1990) programs provided by Bork Group's Advanced Search Services at EMBL (http://www.bork.embl-heidelberg.de:8080).

Anti-sense RNA probes ( ${ }^{32} \mathrm{P}$ labeled, Amersham, Arlington Heights, IL) complementary to the region of the target RNA to be analyzed were synthesized from the fragments cloned into the pGEM vector. Complete runoffs of the transcripts representing the insert anti-sense strand were produced using T7 or SP6 RNA polymerase. The anti-sense riboprobes were produced using a MAXIscrip ${ }^{\mathrm{TM}}$ kit (Ambion, Austin, TX, USA) according to manufacturer instructions. The RPA reactions were performed using a HybSpeed $^{\mathrm{TM}}$ RPA $^{\mathrm{TM}}$ kit (Ambion, Austin, TX, USA). Labeled anti-sense riboprobes that hybridized to complementary RNA in the mixture (which contains the original total RNA extract that originated clones A12B15-6 and A12B131) were protected from ribonuclease digestion, and were then separated on a $5 \%$ polyacrylamide gel and visualized by autoradiography. Other RPA control reactions were conducted using total RNA from other genotypes and water stress treatments as presented in figure 4. A molecular marker (Century ${ }^{\mathrm{TM}}$ Marker Template Plus, Ambion, Austin, TX) was also loaded in the polyacrylamide gel.

\section{RESULTS}

Previous work (Nepomuceno et al., 1998) showed that cotton genotypes Siokra L-23 and T-1521 partially tolerate water deficit stress, whereas genotypes CS 50 and Stoneville 506 show sensitivity. Siokra L-23 and T-1521 exhibited a significant osmotic adjustment in their leaves resulting in water potential remaining near control values during the water deficit stress.

In this study the same sensitive and tolerant cotton genotypes studied by Nepomuceno et al. (1998) were compared for gene expression during water deficit. Fifty-two cDNA fragments originated from mRNA transcripts differentially expressed during water deficit were identified, isolated from the polyacrylamide gels, cloned in pGEM-T vectors, and sequenced. Search of gene bank databases showed that two of these fragments have high homology with known genes. Clone A12B15-6 (271 bp, GenBank accession \# AF056947) has high homology (2.9e-32 P(N); $57 \mathrm{aa}, 69 \%$; figure 1), with a heat shock protein that binds to calmodulin and is found in Nicotiana tabacum. This transcript was differentially expressed only during water defi- 
cit in the two drought tolerant genotypes (Siokra L-23 and T-1521; table 1, figure 2). Lu et al. (1995) isolated the HS protein similar to clone A12B15-6 by screening a 8ZAPII cDNA expression library constructed from cell cultures of heatshocked tobacco (N. tabacum L. cv. Wisconsin-38).

Clone A12B13-1 (323 bp, GenBank accession \# AF056946) showed homology (9.0e-37 P(N), 89aa, 87 \%; figure 1) with an Arabidopsis thaliana trehalose-6-phosphate synthase enzyme (Table1). The trehalose-6-phosphate synthase homologue was also up regulated during water deficit stress but was expressed in all genotypes (figure 3 ). That is an important finding since there are only a few re- ports of trehalose presence in higher plants and no reports of trehalose in cotton. Ribonuclease protection assays confirmed differential expression of clones A12B15-6 and A12B13-1. The cDNA were originated from true mRNA transcripts (figure 4).

The other 50 cDNA fragments showed very low or no homology to known genes and 41 were confirmed by ribonuclease protection assays (data not shown). However, these differentially expressed transcripts might have important roles during plant responses to drought. Identifying the function of these expressed transcripts takes considerable effort and it will be a future focus of our work.

Aminoacid sequence homology between clone A12B15-6 and the calmodulin-binding HSP. Identities $=49 / 82(59 \%)$ - Positives $=57 / 82(69 \%)$

\begin{tabular}{|c|c|c|c|}
\hline A12B15-6: & 251 & ECIYCLACARWAWNRXLHTAGHDSVTWC & 72 \\
\hline & & 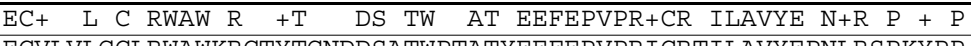 & \\
\hline HSP : & 8 & ECVLVLGCLRWAWKRCTYTGNDDSATWPTATYEEFEPVPRICRTILAVYEPNLRSPKYPP & 67 \\
\hline A12B15-6: & 71 & PGGYGINPDWLILRKTYKDTRG & \\
\hline & & $\mathrm{GGY}+\mathrm{NPDW}+\mathrm{I} \mathrm{R} \mathrm{TY}+\mathrm{T} \mathrm{G}$ & \\
\hline HSP : & 68 & KGGYRLNPDWVI KRVTYEQTSG & \\
\hline
\end{tabular}

Aminoacid sequence homology between clone A12B13-1 and trehalose-6-phosphate-synthase. Identities $=72 / 102(70 \%)$ - Positives $=89 / 102(87 \%)$

\begin{tabular}{l|lllll}
\hline A12B13-1: & 320 & AARDGMNLVPYKYIVCRQGTPGMDEALGVKPEYPRTSMLVVSEFIGCSPSLSGAIRVNPW & 141 \\
\hline Trehalose: & 441 & A RDGMNL+PY+YI+CRQG P ++E +G+ P + SMLVVSEFIGCSPSLSGAIRVNPW \\
\hline A12B13-1: & 140 & $\begin{array}{l}\text { DIDAVAEALNTAITIPESEKQLRHEKHYRYVSTHDVAYWARS } \\
\text { +IDAV EA++ A+ + E+EKQ+RHEKH++YVSTHDVAYWARS }\end{array}$ & 15 \\
\hline Trehalose: & 501 & NIDAVTEAMDYALIVSEAEKQMRHEKHHKYVSTHDVAYWARS & 542
\end{tabular}

Figure 1. Amino acid sequence homology between clones A12B15-6 and A12B13-1 with the calmodulin-binding heat shock protein (HSP), and trehalose-6-phosphate synthase respectively.

Table 1. Clone identification according to their presentation in the DD gel and homologies with know genes.

\begin{tabular}{|c|c|c|c|c|c|c|c|c|c|c|c|c|c|}
\hline 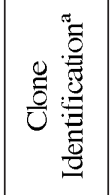 & 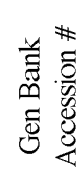 & 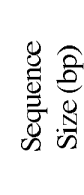 & 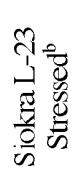 & 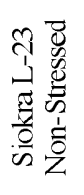 & 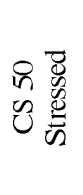 & 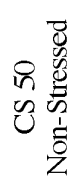 & 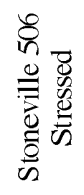 & 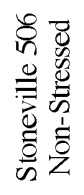 & 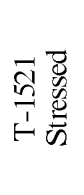 & 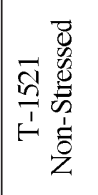 & Homology $y^{\mathrm{c}}$ & 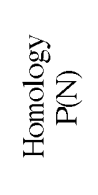 & 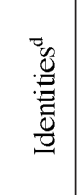 \\
\hline A12B15-6 & 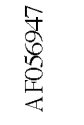 & 271 & +- & -- & -- & -- & -- & -- & ++ & -- & $\begin{array}{c}\text { heat shock protein, } \\
\text { calmodulin-binding } \\
\text { (genbank acc. \# prf/2120412A) }\end{array}$ & $2.9 \mathrm{e}-32$ & $\begin{array}{c}57(\mathrm{aa}) \\
69 \%\end{array}$ \\
\hline A12B13-1 & $\begin{array}{l}\text { 电 } \\
\text { 量 } \\
\text { 要 }\end{array}$ & 323 & ++ & -- & ++ & -- & ++ & -- & ++ & -- & $\begin{array}{c}\text { Trehalose-6-phosphate synthase (genbank } \\
\text { acc. \# sptrembl/O23617) }\end{array}$ & $9.0 \mathrm{e}-37$ & $\begin{array}{c}89 \text { (a) } \\
87 \%\end{array}$ \\
\hline
\end{tabular}

${ }^{a}$ first letter+number $=$ anchor primer; second letter+number $=10$-mer; third number $=$ band position in the dried gel.

$\mathrm{b}$ treatments, ++ represents present band, - represents absent band, +- represents faint band

${ }^{c}$ homology searches using the BLASTN2 and BLASTX2 programs provided by Bork Group's Advanced Search Services at EMBL

d aa - represents amino acid. 


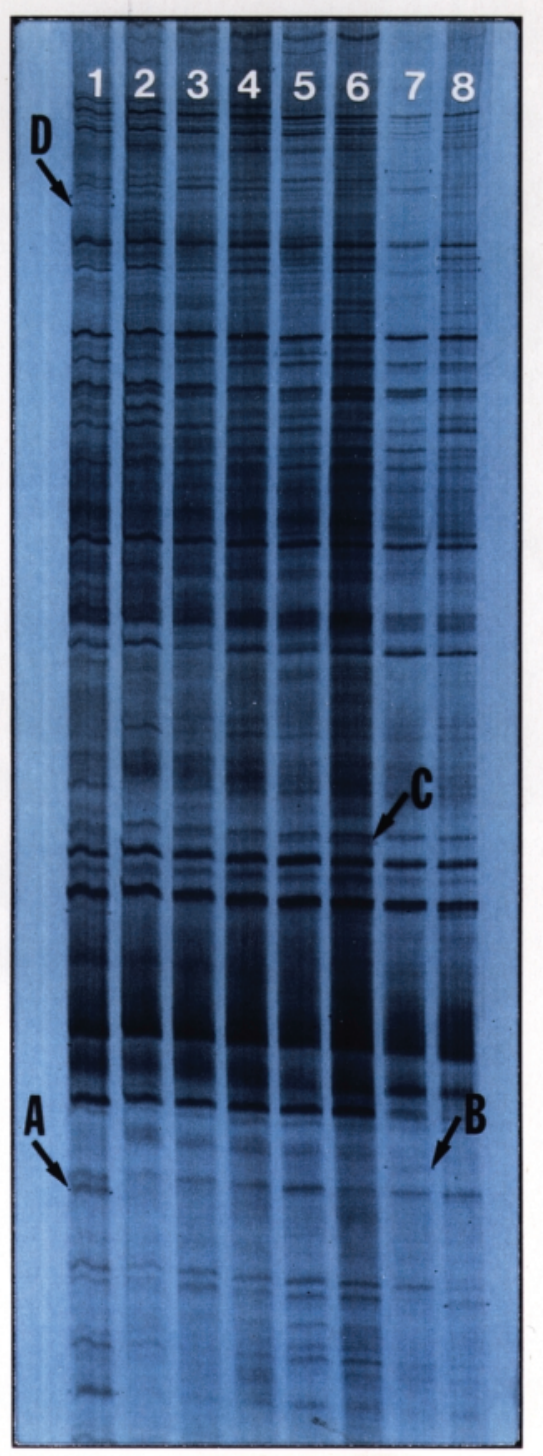

Figure. 2. Differential display (DDRT-PCR) of four cotton genotypes after periods of water deficit. Lane: 1Siokra L-23, stressed; 2- Siokra L-23, non-stressed; 3CS-50, stressed; 4- CS-50, non-stressed; 5- Stoneville 506, stressed; 6- Stoneville 506, non-stressed; 7- T-1521, stressed; 8- T-1521, non stressed. RT-PCR reactions were conducted using anchor primer $\mathrm{A} 12-{ }^{5^{\prime}}(\mathrm{T})_{9} \mathrm{CC}^{3}$ and 10-mer B15- 5'GTGCGTCCTC ${ }^{3}$. cDNA fragments, which appear to be differentially expressed, are indicated by arrows and letters (A - A12B15-5; B - A12B156; C - A12B15-8; D - A12B15-13). cDNA fragment B (A1215-6) show high homology to a HSP. Fragments A, C and D did not show homology to known genes.

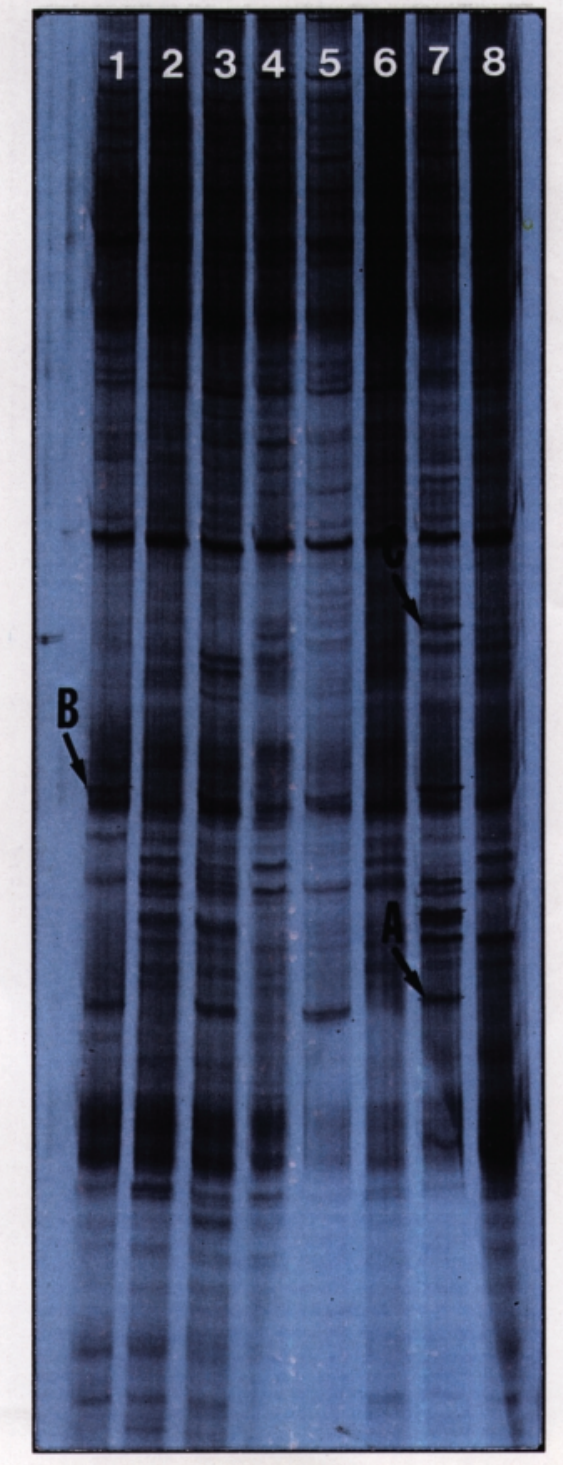

Figure. 3. Differential display (DDRT-PCR) of four cotton genotypes after periods of water deficit. Lane: 1Siokra L-23, stressed; 2- Siokra L-23, non-stressed; 3 CS-50, stressed; 4- CS-50, non-stressed; 5- Stoneville 506, stressed; 6- Stoneville 506, non-stressed; 7- T-1521, stressed; 8- T-1521, non stressed. RT-PCR reactions were conducted using anchor primer $\mathrm{A} 12-{ }^{5^{\prime}}(\mathrm{T})_{9} \mathrm{CC}^{3^{\prime}}$ and 10-mer B13- 5'AAGCTGCGAG ${ }^{3 \prime}$. cDNA fragments, which appear to be differentially expressed, are indicated by arrows and letters (A - A12B13-1; B - A12B134; C - A12B13-6). cDNA fragment A (A12B13-1) show high homology to trehalose-6-phosphate synthase. Fragments $\mathrm{B}$ and $\mathrm{C}$ did not show homology to known genes. 


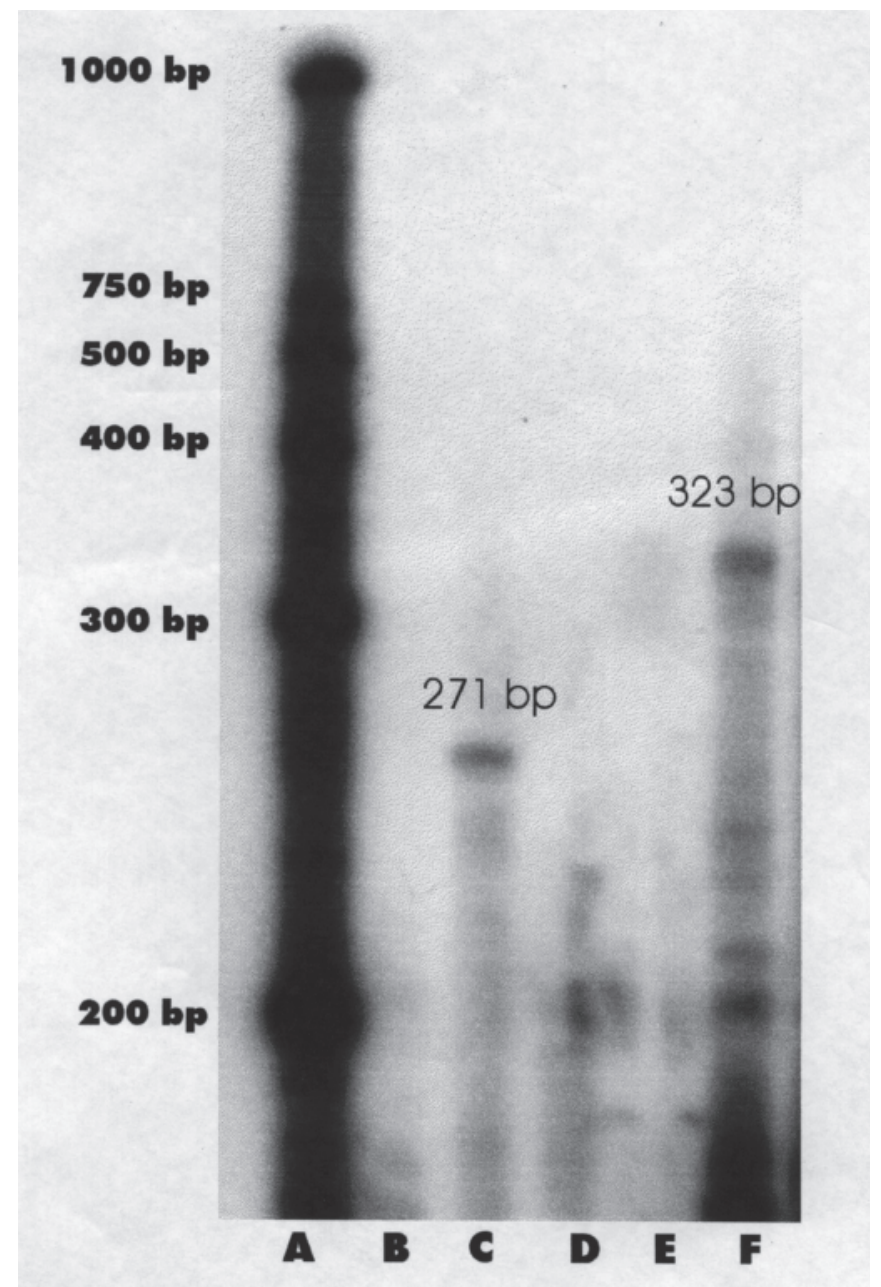

Figure 4. Ribonuclease protection assay. Radiolabed $\left({ }^{32} \mathrm{P}\right)$ probes produced from clones A12B15-6 and A12B13-1 were hybridized with total RNA originally extracted from the treatments. Letters represent: A - Century Plus Marker; B - A12B15-6 probe + Stoneville 506, water-stressed RNA; C - A12B15-6 probe + T-1521 water-stressed RNA; D A12B15-6 + T-1521 non-water-stressed RNA; E - A12B131 probe + Siokra L-23, non water-stressed RNA; F A12B13-1 probe + Siokra L-23, water-stressed RNA.

\section{DISCUSSION}

Heat Shock Protein: Water-deficit responses are complex. Tolerance could be conferred by dozens of genes being expressed in a precise arrangement or by a single gene that is a key player in a specific pathway. Clone A12B15-6 was differentially expressed only during water deficit in the two drought tolerant genotypes (Siokra L-23 and T1521; table 1, figure 2). Most of the HSP seem to function as molecular chaperones that assist in protein folding and prevention of protein denaturation (Zhu et al., 1993). Water deficit, osmotic stress and cold stress are some of the abiotic stresses that aggravate protein aggregation and denaturation, making production of HS proteins more necessary. Finding a HSP with homology to a calmodulin-binding protein is an interesting result considering the important role calmodulin $(\mathrm{CaM})$ plays in calcium-mediated processes, enzyme activity and signal transduction (Roberts and Harmon, 1992; Poovaiah and Reddy, 1993). Many studies show that $\mathrm{CaM}$ associates with other proteins in a calcium-dependent manner. CaM senses nanomolar changes in $\mathrm{Ca}^{2+}$ and acts as a molecular switch to regulate other proteins and enzymes. These target enzymes and proteins are thought to be the response elements through which the $\mathrm{Ca}^{2+} / \mathrm{CaM}$ second-messenger system ultimately affects signal transduction (Lu et al., 1995). Although the whole gene, of which clone A12B15-6 is only a part, still needs to be sequenced, the homology found between this $271 \mathrm{bp}$ fragment and a calmodulin-binding protein opens an attractive line of study. Calmodulin-binding proteins, like clone A12B15-6, have been observed under a large number of cellular conditions, however, their actual significance as regulatory proteins is still unknown (Ling et al., 1994). Heat shock proteins that bind to $\mathrm{CaM}$ could be involved in regulation of $\mathrm{Ca}^{2+}$ mediated processes. This involvement may range from performing as a chaperone to stabilize $\mathrm{CaM}$ and avoid loss of activity during stress to participating of the stress response system as a component enzyme.

The $\mathrm{Ca}^{2+} / \mathrm{CaM}$ complex appears to play key roles in plant metabolism, thus understanding some of the $\mathrm{Ca}^{2+}$ action responses is critical. Significantly, a $\mathrm{Ca}^{2+}$ signal transduction pathway is involved in turgor regulation in plant cells (Coté, 1995). One of the first known responses of guard cells to abscisic acid (ABA) is an increase in cytosolic $\mathrm{Ca}^{2+}$, where stomatal closure is induced by release of $\mathrm{Ca}^{2+}$ into the cytoplasm (McAinsh et al., 1990; Schroeder and Hagiwara, 1990). If stomatal control is one of the mechanisms regulated by the $\mathrm{Ca}^{2+} / \mathrm{CaM}$ association, clone A12B15-6 might be related to the water-deficit tolerance found in Siokra L-23 and T-1521, since this transcript was expressed only during water deficit and only in these two genotypes (figures 2 and 4, table 1). Both genotypes showed the ability to keep photosynthesis near control levels during water deficit (Nepomuceno et al., 1998). Photosynthesis is directly related to leaf water status, and consequently, the control of water loss through transpiration and stomatal opening is strategically important. Atight molecular regula- 
tion of these mechanisms needs to be in place. The presence of this HS protein differentially expressed during water stress in both tolerant genotypes indicates a possible signal transduction pathway related to their tolerance mechanisms. Even though more studies are necessary, the unique expression of these genes, confirmed by RPA, makes it possible to use them as probes to identify other genotypes presenting the same characteristics.

Trehalose-6-Phosphate Synthase: This enzyme is involved in the production of trehalose, a disaccharide known to provide osmotic protection of cell membranes during dehydration (Crowe et al., 1993; Muller et al., 1995; Majara et al., 1996). The presence and up-regulation of trehalose-6phosphate synthase (figure 3) during water deficit seems to be a good indication that trehalose is produced in all four cotton genotypes during the stress. This is an exciting finding considering that there are only a few reports of trehalose in higher plants (Muller et al., 1995), and no reports of trehalose in cotton. The presence of trehalose in microorganisms and invertebrate animals is well documented. Although there are a few reports of higher plants synthesizing trehalose, some researchers still argue that trehalose in higher plants originates from symbiosis (Ghittoni and Bueno, 1995; Avigad and Dey, 1997) or contamination (Gussin, 1972) with bacteria and/or fungi that produce trehalose.

Trehalose has been reported in more than 70 species of desiccation-tolerant plants, mostly among lower classes (Ushiyama and Furuga, 1989; Drennan et al., 1993; Muller et al., 1995). The production of trehalose in higher plants seems to be open to speculation, since the trehalase activity is usually high in higher plants (Kendall et al., 1990). In terms of evolution, the question to be asked is: if plants do not produce trehalose, why is trehalase activity observed? Maybe trehalose is produced in higher plants, like the sequence of clone A12B13-1 suggests for cotton, but high trehalase activity might be degrading it as fast as it is produced. Goddijn et al. (1997) demonstrated that inhibition of trehalase in wild-type potato (Solanum tuberosum) significantly increased trehalose concentrations in potato tissues. The importance of this result is that it was obtained using in vitro material, thus a possible bacterial or fungal origin of trehalose can be excluded. Furthermore, gene transcripts that are homologous to trehalose- 6-phosphate synthase and treahalose-6-P-phosphatase were also found in A. thaliana (Goddijn et al., 1997). Together with our findings these results suggest that, in opposition to the current idea, angiosperms have the capacity to synthesize trehalose. Trehalose presence may not have been demonstrated because of the trehalase activity. One interesting approach of addressing this controversy would be to inhibit trehalase activity by use of antisense technology.

Disaccharides, like trehalose, appear to be one of the most effective stabilizers of dried enzymes and cell membranes in vitro and in vivo. However, the interaction of trehalose with membranes has been studied more than its interactions with proteins. Even though the mechanism by which trehalose stabilizes proteins is unclear, Carpenter (1993) suggested that trehalose probably interacts directly with dry protein by hydrogen bonding - $\mathrm{OH}$ groups to polar residues in the protein. Studies of the interaction between trehalose and phospholipid bi-layers indicate that trehalose replaces water molecules around the polar head groups of the phospholipid in the dry state (Gaber et al., 1986). This hypothesis has been discussed and direct evidence for trehalose binding to phospholipid membranes has been obtained for dry phospholipid vesicles (Potts, 1994). The interaction of trehalose with the membrane lowers the $\mathrm{T}_{\mathrm{m}}$ (melting temperature) of the membrane enabling it to keep its liquid crystalline phase during desiccation (Crowe et al., 1993). To give its protective effects, trehalose must be present on both sides of the membrane. Thus, for effective protection a transporter to carry trehalose across the cell membrane is needed (Crowe et al., 1993; Potts, 1994).

For figure 3 and table 1, it can be seen that band A appears in all four genotypes during the stress. Considering the discussion above, genotypes that lack or have reduced trehalase activity (Goddijn et al., 1997) might express higher water-deficit tolerance because trehalose will be present. Also, genotypes lacking a transporter to move trehalose to both sides of the membrane will be more sensitive to deficit. The combination of these two or other possibilities should be considered when analyzing the physiological and genetic characterization of the genotypes studied here. Both Siokra L-23 and T-1521 show a significant osmotic potential decrease during the applied stress (Nepomuceno et al., 1998). Presence of active trehalose might be one of the factors involved in this result. 


\section{REFERENCES}

Altschul SF, Gish W, Miller W, Myers EW, Lipman DL (1990) Basic local alignment search toll. J. Mol. Biol. 215:403-410.

Ausubel F, Brent R, Kingston RE, Moore DD, Seidman JG, Smith AJ, Struhl K (1995) Short protocols in molecular biology. John Wiley \& Sons, New York.

Avigad G, Dey PM (1997) Carbohydrate metabolism: storage carbohydrates. In: Dey PM, Harborne JB (eds.), Plant Biochemistry, pp. 143-204. Academic Press, San Diego, CA.

Boyer JS (1996) Advances in drought tolerance in plants. Adv. Agron. 56:187-218.

Bray EA (1993) Molecular responses to water deficit. Plant Physiol. 103:1035-1040.

Bray EA (1997) Plant responses to water deficit. Trends Plant Sci. 2:48-54.

Carpenter JF (1993) Stabilization of proteins during freezing and dehydration:application of lessons from nature. Cryobiology 30:220-221.

Carpenter JF, Crowe LM, Crowe JH (1987) Stabilization of phosphofructokinase with sugars during freeze-drying: Characterization of enhanced protection in the presence of divalent cations. Biochim. Biophys. Acta 923:109-15.

Cooper GM (1997) The cell: A molecular approach. ASM Press, Washington, D.C.

Coté GG (1995) Signal transduction in leaf movement. Plant Physiol. 109:729-734.

Crowe JH, Crowe LM, Leslie SB, Fisk E (1993). Mechanisms of stabilization of dry biomolecules in anhydrobiotic organisms. In: Close TJ, Bray EA (eds.), Plant Responses to Cellular Dehydration During Environmental Stress, pp. 11-20. Amer. Soc. Plant Physiology, Riverside, CA.

Drennan P, Smith M, Goldsworthy D, Staden J (1993) The occurrence of trehalose in the leaves of the dessicationtolerant angiosperm Myrothamnus flabellifolius Welw. Plant Physiol. 142: 493-496.

Gaber BP, Chandrasekhar I, Pattabiraman N (1986). The interaction of trehalose with the phospholipid bilayer: a molecular modeling study. In: Leopold AC (ed.), Membranes, metabolism and dry organisms, pp. 231241. Cornell University Press, Ithaca, NY.
Ghittoni NE, Bueno MA (1995) Peanut rhizobia under salt stress: role of trehalose accumulation in strain ATCC 51466. Can. J. Microbiol. 41:1021-1030.

Goddijn OJM, Verwoerd TC, Voogd E, Krutwagen RWHH, Graaf PTHM, Poels J, Dun K, Kees, Ponstein AS, Damm B, Pen J (1997). Inhibition of trehalase activity enhances trehalose accumulation in transgenic plants. Plant Physiol. 113:181-190.

Gussin A (1972) Does trehalose occur in angiospermae? Phytochemistry 11:1827-1828

Harborne JB (1997) Biochemical plant ecology. In: Dey PM, Harborne JB (eds.), Plant Biochemistry, pp. 501516. Academic Press, San Diego, CA.

Hare P, Plessis SP, Cress W, Staden JV (1996) Stress-induced changes in plant gene expression. South Afr. J. Sci. 92:431-439.

Henvitt EJ (1963) Mineral nutrition of plants in culture media. In: Stewart FC (Ed.), Plant Physiology pp. 97134. Academic Press, New York.

Holt SW (1995) A hierarchical evaluation of selected growth phenomena in reproductive structures of Gossypium hirsutum L. Fayetteville, University of Arkansas. PhD thesis.

Ingram J, Bartels D (1996) The molecular basis of dehydration tolerance in plants. Annu. Rev. Plant Physiol. Plant Mol. Biol. 47:377-403.

Joshi CP, Nguyen HT (1996) Differential display-mediated rapid identification of different members of a multigene family, HSP16.9 in wheat. Plant Mol. Biol. 31:575-584.

Kendall EJ, Adams RP, Kartha KK (1990) Trehalase activity in plant tissue cultures. Phytochemistry 29:25252528.

Lehninger AL, Nelson DL, Cox MM (1993) Cell. In: Lehninger AL, Nelson DL, Cox MM (eds.), Principles of Biochemistry, pp. 21-55, Worth Publishers, New York.

Leprince O, Hendry GAF, McKersie BD (1993) The mechanisms of disiccation tolerance in developing seeds. Seed Sci. Res. 3:231-46.

Ling V, Snedden WA, Schelp BJ, Assman S (1994) Analysis of a soluble calmodulin-binding protein from fava bean roots: identification of glutamate decarboxylase as a calmodulin-stimulated enzyme. Plant Cell 6: 1135-1143. 
Lu YT, Dharmasiri MA, Nihal N, Harrington HM (1995) Characterization of a cDNA encoding a novel heatshock protein that binds to calmodulin. Plant Physiol. 108:1197-1202.

Majara M, O'Connor-Cox ESC, Axcell BC (1996) Trehalose - A stress protectant and stress indicator compound for yeast exposed to adverse conditions. J. Am. Soc. Brew. Chem. 54:221-227.

McAinsh MR, Brownlee C, Hetherington AM (1990) Abscisic acid-induced elevation of guard cell cytosolic $\mathrm{Ca}^{2+}$ precedes stomatal closure. Nature 343:186-188.

Muller J, Boller T, Wiemken A(1995) Trehalose and Trehalase in plants: Recent developments. Plant Sci. 112:1-9.

Nepomuceno AL, Oosterhuis DM, Stewart JM (1998) Physiological responses of cotton leaves and roots to water deficit induced by polyethylene glycol. Environ. Exp. Bot. 40:29-41.

Nepomuceno AL, Oosterhuis DM, Stewart JM (1996) Characterization of water deficit stress in cotton genotypes by measuring water and osmotic potential in roots and leaves. In: Proceedings of the 1996 cotton research meeting, pp. 96-101. Ark. Agr. Exp. Stat. Special Report 178 .

Oosterhuis D, Wullschleger SD, Stewart JM (1987). Osmotic adjustment in commercial cultivars and wild types of cotton. Agron. Abstracts, p. 57.

Poovaiah BW, Reddy ASN (1993) Calcium and signal transduction in plants. CRC Crit. Rev. Plant Sci. 12:185-211.

Potts M (1994) Desiccation tolerance of prokaryotes. Microbiol. Rev. 58:755-805.

Roberts DM, Harmon AC (1992) Calcium-modulated proteins: targets of intracellular calcium signals in higher plants. Annu. Rev. Plant Physiol. Mol. Biol. 43:375-414.

Sambrook J, Fritsch EF, Maniatis T (1989) Molecular cloning: A laboratory manual. $2^{\text {nd }}$ edn. Cold Spring Harbor Press, Cold Spring Harbor, New York.
Schroeder JI, Hagiwara S (1990) Repetitive increases in cytosolic $\mathrm{Ca}^{2+}$ of guard cells by abscisic acid activation of nonselective $\mathrm{Ca}^{2+}$ permeable channels. Proc. Natl. Acad. Sci. USA 87:9305-9309.

Shen B, Jensen RG, Bohnert HJ (1997) Mannitol protects against oxidation by hydroxyl radicals. Plant Physiol. 115:527-532.

Shinozaki K, Yamaguchi-Shinozaki K (1996) Molecular responses to drought and cold stress. Curr. Opin. Biotechnol. 7:161-167.

Shinozaki K, Yamaguchi-Shinozaki K (1997) Gene expression and signal transduction in water-stress response. Plant Physiol. 115:327-334.

Song P, Yamamoto E, Allen RD (1995) Improved procedure for differential display of transcripts from cotton tissues. Plant Mol. Biol. Rep. 13:174-181.

Turner NC (1997) Further progress in crop water relations. Adv. Agron. 58:293-338.

Ushiyama M, Furuga T (1989) Biotransformation of (RS)tropic acid in suspension cultures of Coffea arabica, Datura innoxia, Eucalyptus perriniana and Nicotiana tabacum Phytochemistry 28:2333-2339.

Vierling E (1991) The roles of heat shock proteins in plants. Annu. Rev. Plant Physiol. Plant Mol. Biol. 42:579-620.

Wan C, Wilkins TA (1994) A modified hot borate method significantly enhances the yield of high-quality RNA from cotton (Gossypium hirsutum L.) Anal. Biochem. 223:1-6.

Wan JS, Sharp SJ, Poirier GMC, Wagaman JC, Pyati J, Hom Y, Galindo JE, Huvar A, Peterson PA, Jackson MR, Erlander MG (1996) Cloning differentially expressed mRNAs. Nature Biotechnol. 14:1685-1691.

Zhu J K, Shi J, Bressan RA, Hasegawa PM (1993) Expression of an Atriplex nummularia gene encoding a protein homologous to the bacterial molecular chaperone DNA. J. Plant Cell 5:341-349.

Zhu J, Hasegawa PM, Bressan RA (1997) Molecular aspects of osmotic stress in plants. Crit. Rev. Plant Sci. 16:253-27. 